\title{
PERAN AYAH DAN KONTROL DIRI SEBAGAI PREDITOR KECENDERUNGAN PERILAKU AGRESIF REMAJA
}

\author{
Nina Zulida Situmorang1, Yuliatmi Pratiwi ${ }^{2}$, dan Dimas Panji Agung R. ${ }^{3}$ \\ ${ }^{1}$ Fakultas Psikologi, Universitas Ahmad Dahlan \\ Email : nina.situmorang@psy.uad.ac.id \\ ${ }^{2}$ Fakultas Psikologi, Universitas Ahmad Dahlan \\ Email: yuliatmi.pratiwi@gmail.com \\ ${ }^{3}$ Fakultas Psikologi, Universitas Ahmad Dahlan \\ Email: dimaspanji279@gmail.com
}

\begin{abstract}
ABSTRAK
Remaja dituntut untuk dapat mengendalikan emosinya agar tidak terjerumus pada perilaku agresif. Namun pada kenyataanya remaja juga sering dihadapkan pada konflik-konflik internal, sebagai akibat dari adanya perubahan baik secara fisik maupun secara psikis. Akibat konflik-konflik internal ini sedikit banyak mempengaruhi perilaku dan cara pandang remaja terhadap lingkungan sekitar.. Perasaan akibat konflik tersebut cenderung membuat remaja lebih mudah marah dan berperilaku agresif. Faktor peran ayah dan kontrol diri berdasarkan pra penelitian memberi kontribusi meningkatkan atau mengurangi kecendrungan perilaku agresif. Tujuan penelitian untuk menguji hubungan peran ayah dan kontrol diri dengan kecendrungan perilaku agresif pada remaja laki-laki di Yogyakarta. Metode penelitian menggunakan metode kuantitatif. S ampel penelitian sejumlah 129 siswa SMA di Yogyakarta dengan menggunakan cluster sampling. Metode pengumpulan data menggunakan skala peran ayah, skala, kontrol diri dan skala kecendrungan perilaku agresif. Teknik analisis data dengan menggunakan analisis regresi ganda. Hasil penelitian menunjukkan (1) Ada hubungan signifikan peran ayah da $n$ kontrol diri terhadap kecendrungan perilaku agresif pada remaja dengan $r=0.127 ; p<0.01 .(2 . T e r d a p a t$ hubungan signifikan peran ayah terhadap kecenderungan perilaku agresif pada remaja dengan $t=-2.21 ; p<0.05$ (3).Terdapat hubungan signifikan antara kontrol diri dengan kecenderungan perilaku agresif remaja $t=3.556 ; p<0.01$. Simpulan menunjukkan ada hubungan antara peran ayah dan kontrol diri terhadap kecendrungan perilaku agresivitas siswa SMA di Yogyakarta.
\end{abstract}

Kata Kunci: peran ayah, kontrol diri, kecendrungan perilaku agresif

\section{PENDAHULUAN}

Perkembangan remaja merupakan fase peralihan usia anak menuju dewasa. Masa remaja berlangsung pada usia 12-21 tahun, dengan penjabaran pada usia 12-15 tahun disebut sebagai remaja awal, 15-18 tahun disebut sebagai remaja tengah dan 18-21 tahun disebut sebagai remaja akhir (Monks, 2001). Pada usia remaja terjadi perkembangan baik secara fisik dan biologis yang berhubungan dengan perasaan dan pemikiran serta perkembangan emosional yang tidak stabil, begitu juga dengan perkembangan dalam aspek-aspek kejiwaan remaja dan membuat remaja menjadi bingung antara kehidupan dan kenyataan. Masa remaja penuh dengan gejolak emosi dan tidak keseimbangan yang tercakup dalam masa strom dan stress yang membuat remaja terpengaruh oleh lingkungannya (Gunarsa, 2007).

Tugas perkembangan remaja menurut Hurlock (2004), diantaranya adalah menuju kemandirian emosional dan mengembangkan perilaku sosial yang bertanggung jawab yang diperlukan untuk memasuki dunia dewasa. Remaja diharapkan mampu mengelola emosi dan bertanggung-jawab terhadap segala perilakunya agar tidak terjerumus antara lain pada perilaku agresi. Kenyatannya remaja sering dihadapkan pada perubahan baik secara fisik maupun secara psikis yang memunculkan konflikkonflik internal yang memengaruhi perilaku dan cara pandang remaja terhadap lingkungan sekitar. Cara pandang yang muncul seperti pemikiran kritis, perasaan yang mudah tersinggung, cita-cita dan kemauan yang tinggi tetapi sukar untuk diraih 
sehingga ia merasa frustasi yang membuat remaja lebih mudah marah dan berperilaku agresif (Nisfiannoor \& Yulianti, 2005).

Kecendrungan perilaku agresif dikalangan remaja menunjukkan trend yang cukup memprihatinkan yang dapat terekam dari berbagai media yang memberitakan antara lain tawuran pada pelajar Sekolah Menegah Pertama maupun Sekolah Menengah Atas. Terjadi peningkatan pada peristiwa kekerasan fisik, kekerasan seksual dan kekerasan psikis (BPS, 2010).

Pada tahun 2007, terdapat angka 3145 remaja usia $\leq 18$ tahun menjadi pelaku tindak kriminal, tahun 2008 dan 2009 meningkat menjadi 3280 hingga 4123 remaja. Data dari Komnas Perlindungan Anak (2013), terjadi peningkatan kasus tawuran dari tahun 2012 sebanyak 147 dengan korban meninggal dunia sebanyak 82 orang, hingga tahun 2013 sebanyak 255 kasus dengan korban meninggal dunia sebanyak 20 orang. Selain itu kasus pelajar pengguna narkoba dari tahun 2008 sampai 2012 yaitu sebanyak 654 tahun 2008 , 635 kasus tahun 2009, 531 kasus tahun 2010, 605 kasus tahun 2011, dan 695 kasus tahun 2012 (Kementerian Kesehatan RI, 2014).

Remaja di Yogyakarta juga mengalami perluasan fenomena perilaku agresivitas. Kota Yogyakarta yang dihuni dari berbagai masyarakat dari daerah di seluruh Indonesia selain sebagai sebagai kota pusat pendidikan juga tujuan wisata domestik dan mancanegara. Perkelahian antar siswa dan geng motor menjadi permasalahan yang muncul. Kekerasan remaja di Yogyakarta dikenal dengan istilah ngelitih/klitih. Suatu istilah yang awalnya diartikan sebagai mencari kesibukan di saat senggang. Klitih dikenal dalam konteks kenakalan remaja adalah berkeliling menggunakan kendaraan bermotor yang dilakukan sekelompok oknum kelompok pelajar. Biasanya mereka mencari pelajar sekolah lain yang dianggap sebagai musuh untuk kemudian diserang dengan senjata tajam seperti pedang samurai, clurit, pisau, atau perlengkapan lain yang telah disiapkan. Namun Klitih juga bisa diasumsikan putar-putar kota kemudian melakukan aksi vandalisme menggunakan cat semprot ( Say, 2016).

Menurut Baron (2005) agresi adalah bentuk perilaku yang disengaja terhadap makhluk lain dengan tujuan untuk melukai atau membinasakan seseorang, sedangkan orang yang diserang berusaha untuk menghindar. Baidi (2008) menjelaskan bahwa perilaku agresif adalah kecenderungan berperilaku yang ditunjukan pada makhluk hidup maupun benda mati dengan maksud melukai, menyakiti, mencelakakan atau merusak dengan menimbulkan kerugian secara fisik atau psikologis pada seseorang yang tidak ingin dirugikan atau mengakibatkan kerusakan pada benda. Definisi lain disampaikan Chen (2017) menjelaskan perilaku agresif dapat didefinisikan sebagai perilaku yang dimaksudkan untuk menyakiti orang lain, dan hal ini terkait dengan banyak faktor individu dan sosial.

Kecenderungan perilaku agresif yang dilakukan remaja menjadi masalah yang serius karena tindakan-tindakan tersebut mengarah ke tindakan kriminal. Faktor penentu perilaku agresif yang utama yakni rasa marah dan proses belajar respon agresif (Sears, Freedman, \& Peplau, 1991). Proses belajar tersebut dapat terjadi melalui respon agresif atau melalui imitasi. Beberapa faktor yang berhubungan perilaku agresif diantaranya adalah provokasi yang disebabkan adanya usaha untuk membalas sifat orang lain, kondisi aversif yang merupakan kondisi tidak menyenangkan yang biasanya dihindari oleh seseorang dan adanya isyarat agresif yang diasosiasikan sebagai sumber perbuatan agresif (Mahmudah, 2010). 
Hasil wawancara pada pihak sekolah salah satu SMKN di Yogyakarta pada tanggal 20 Maret 2017 menemukan fakta terdapat beberapa siswa yang sengaja berperilaku agresif seperti memukul, menendang dan menghardik temannya dengan kata kasar, sehingga menyebabkan sakit fisik maupun psikis. Perilaku agresif tidak hanya dilakukan siswa terhadap temannya saja, namun juga terhadap guru seperti melawan dan mencemooh guru ketika belajar. Hal ini mengakibatkan siswa berperilaku agresif dijauhi oleh teman-temannya dan membuat guru tidak senang dengan siswa tersebut.

Dampak perilaku agresif dapat dilihat pada pelaku dan korban. Dampak pada pelaku misalnya pelaku akan dijauhi dan tidak disenangi oleh orang lain. Sedangkan dampak pada korban, misalnya timbulnya sakit fisik dan psikis serta kerugian akibat perilaku agresif tersebut.

Remaja yang agresif memiliki toleransi yang rendah terhadap frustasi dan kurang mampu menunda kesenangan (Myres, 2002; Larson, 2008), cenderung bereaksi dengan cepat terhadap dorongan agresinya, kurang dapat melakukan refleksi diri (Currie, 2004), dan kurang dapat bertanggung jawab atas akibat perbuatannya (Knorth, Klomp, Van der Bergh, \& Noom, 2007).

Banyak faktor yang mempengaruhi kecendrungan perilaku agresif pada remaja antara lain faktor biologis, temperamen yang sulit, pengaruh pergaulan yang negatif, penggunaan narkoba, pengaruh tayangan kekerasan, merasa kurang diperhatikan oleh orang tua, tertekan, pergaulan buruk dan kondisi keluarga dan lain sebagainya. Berdasarkan penelitian longitudinal terhadap remaja, Elliot (Tremblay \& Cairns, 2000) menemukan bahwa peningkatan tindakan kekerasan pada anak laki-laki maupun perempuan pada usia 12 tahun sampai 17 tahun.

Salah satu penyebab munculnya keberanian mengambil risiko (risk-taking) pada remaja menurut Lerner (2011) dikarenakan hilangnya peran ayah. Hilangnya peran ayah pada anak dapat menimbulkan dampak yakni masalah gangguan kecemasan dan depressi pada anak (Kandel, Rosenbaum \& Chen, 1994), terlibat dengan aktifitas seksual dini, penyalahgunaan obat-obatan, gangguan mood, serta terlibat kenakalan serius atau bahkan tindakankriminal (Fergusson, Horwood, \& Lynsky, 1994) dan memiliki masalah gangguan kecemasan dan depresi (Block. 1998).

Seperti budaya yang berkembang di Indonesia, anak biasanya lebih dekat dengan ibu atau nenek karena mereka lebih banyak berada di rumah. Ayah biasanya sibuk bekerja di luar rumah sehingga jarang memperhatikan anak-anaknya. Saat di rumah, biasanya lebih menyerahkan pada kaum ibu untuk mendidik anak-anak. Hasil ini mendukung penelitian Andayani dan Koentjoro (2007) memberikan gambaran bahwa peran ayah cenderung rendah dalam proses pengasuhan, ayah cenderung menjaga jarak dari anak-anaknya.

Penelitian yang s a m a pada anak yang tidak tinggal dengan ayah dan ibunya menunjukkan adanya perilaku penyalahgunaan narkoba (Hoffman, 2002). Remaja yang memiliki ayah yang banyak terlibat dalam kehidupan mereka dan mendiskusikan pentingnya keputusan mereka menunjukan tingkat agresi yang lebih rendah dibandingkan dengan remaja dengan ayah yang kurang terlibat dalam aktifitas mereka. Ayah akan mempengaruhi anak dengan cara yang berbeda dengan para ibu, terutama di bidang-bidang seperti hubungan anak dengan 
teman sebaya dan prestasi akademis. Penelitian selanjutnya menunjukan bahwa anak yang memiliki ayah yang terlibat secara emosional dalam kehidupan anak akan menunjukan keterampilan bergaul dan nilai akademik yang baik, sebaliknya ayah yang menunjukkan sikap menghina, meremehkan dan memarahi, membuat anak cenderung berperilaku agresif (Subiyanto, 2004).

Emosi marah menjadi pemicu umum dari agresifitas saat seseorang mengalami suatu kondisi emosi tertentu. Kemarahan dapat membuat seseorang kehilangan kontrol diri dan berperilaku agresif (Sarwono \& Eko, 2009). Secara umum, kemampuan manusia untuk menahan dan mengendalikan perilaku sosial yang tidak pantas lebih dikenal sebagai kontrol diri atau pengendalian diri. Pengendalian diri dapat membantu respon ketika dorongan agresif tersebut aktif dan membantu respon menyesuaikan diri dengan standar pribadi atau sosial yang memperingatkan perilaku agresif (Gottfredson \& Hirschi, 1990).

Kontrol diri dikatakan sebagai kemampuan manusia untuk menahan dan mengendalikan perilaku sosial yang tidak pantas (DeWall, Baumeister, Stillman \& Gailliot, 2005). Hal ini didukung oleh hasil penelitian DeWall, Finkel, dan Denson (2011) yang menyatakan bahwa kegagalan kontrol diri dapat memberikan kontribusi untuk tindakan yang paling agresif yang menyertakan kekerasan. Penjelasan lain juga menunjukkan bahwa individu yang memiliki sifat pengendalian diri yang rendah lebih mungkin untuk terlibat dalam perilaku kriminal dan menyimpang dibandingkan dengan mereka yang memiliki tingkat kontrol diri yang tinggi (McMullen, 1999).

Ketika munculnya perilaku agresif, kontrol diri dapat membantu seseorang merespon sesuai dengan standar pribadi atau sosial yang dapat menahan munculnya perilaku agresi (DeWall, Finkel \& Denson, 2011). Secara garis besar dapat disimpulkan bahwa kontrol diri berkaitan dengan bagaimana individu mengendalikan emosi serta dorongan dari dalam dirinya sehingga mampu membuat keputusan dan mengambil tindakan yang efektif terutama untuk membawa mereka sesuai dengan standar ideal, nilai-nilai moral dan harapan sosial. Kurangnya ketelibatan peran ayah dalam keluarga memiliki dampak apda remaja, dan jika disertai lemahnya pengelolaan control diri dapat membuat remaja senang melakukan tindakan beresiko dan melanggar aturan tanpa memikirkan efek jangka panjangnya.

Hasil penelitian DeWall, Baumeister, Stillman dan Galliot (2013) mengenai efek regulasi diri atau kontrol diri dan pengurangan regulasi diri kepada agresi menunjukkan bahwa regulasi diri dalam diri individu merupakan suatu sumber daya yang terbatas dan sangat mungkin untuk habis. Apabila sumber daya akan regulasi diri dalam diri individu telah habis, maka perilaku agresif menjadi lebih mungkin terjadi saat peristiwa eksternal merangsang impuls agresif. Individu yang memiliki kemampuan terbatas untuk menahan diri dari perilaku agresif lainnya, apabila kemampuan kontrol diri dalam individu berkurang maka hal tersebut dapat menghambat kemampuan untuk menahan perilaku agresif. Sedangkan, orang-orang yang memiliki pengendalian diri yang tinggi cenderung lebih tahan terhadap pengaruh untuk memunculkan agresfitasnya. Keterlibatan peran ayah dalam mengasuh anak dan control diri pada remaja merupakan penyebab perilaku agresif, yang menjadi alasan dilakukan penelitian ini. Peneliti ingin menguji apakah peran ayah dalam pengasuhan dan kontrol diri berkontribusi terhadap kecenderungan perilaku agresif remaja. 


\section{METODE PENELITIAN}

Metode yang digunakan dalam penelitian ini dengan metode kuantitatif dengan menggunakan analisis regresi berganda. Populasi dalam penelitian ini adalah pelajar salah satu SMK di DI Yogyakarta yang berusia16 -17 tahun kelas X. Sampel adalah sebagian dari anggota populasi dan dalam penelitian ini sampel menggunakan 128 siswa dan siswi. Metode pengambilan sampel menggunakan teknik purposive sampling yakni teknik penentuan sampel dengan pertimbangan tertentu, dengan kata lain unit sampel yang dihubungi disesuaikan dengan kriteria tertentu yang ditetapkan berdasarkan tujuan penelitian. Peneliti meminta bantuan dari guru Bimbingan Konseling (BK) yang bertugas untuk memilih kelas mana yang memiliki kecenderungan perilaku agresif.

Pengumpulan data dilakukan dengan skala kecenderungan perilaku agresifitas, skala peran ayah dan skala kontrol diri. Skala kecenderungan perilaku agresifitas, skala peran ayah dan skala kontrol diri menggunakan jawaban (S) Sering, (K) Kadang-kadang, (J) Jarang, (TP) Tidak Pernah. Pada item favorable (S) Sering diberi skor 4, (K) Kadang-kadang diberi skor 3, (J) Jarang diberi skor 2, (TP) Tidak Pernah diberi skor 1.

Skala kecendrungan agresifitas diadaptasi dari Buss dan Perry (1992) yaitu berdasarkan bentuk agresi fisik (physical aggression), agresi verbal (verbal aggression), kemarahan (anger), dan permusuhan (hostility). Skala setelah adaptasi menghasilkan 40 item. Hasil analisis item mendapatkan 24 item yang dianggap realibel digunakan untuk penelitian. Cronbach Alpha pada skala ini sebesar 0,818 .

Skala peran ayah diadaptasi dari Lamb (2010) yang meliputi keterlibatan secara langsung (engagement), kehadiran atau kesediaan ayah untuk anak (accessibility), memahami dan memenuhi kebutuhan anak (responsibility). Skala peran ayah setelah adaptasi menghasilkan 33 item. Hasil analisis item mendapatkan 27 item yang dianggap realibel digunakan untuk penelitian. Cronbach Alpha pada skala ini sebesar 0,965.

Skala kontrol diri diadaptasi berdasarkan aspek-aspek kontrol diri yang dikembangkan oleh Averill (1983) yaitu: kontrol perilaku, kontrol kognitif dan kontrol kepuasan. Skala setelah adaptasi menghasilkan 45 item dan hasil analisis item mendapatkan 20 item yang dianggap realibel. Cronbach Alpha pada skala ini sebesar 0,805.

Penelitian ini mengajukan tiga hipotesis yakni: (1) Ada hubungan sangat signifikan peran ayah dan kontrol diri terhadap kecenderungan perilaku agresif pada remaja; (2) Ada hubungan signifikan peran ayah terhadap kecenderungan perilaku agresif; (3) Ada hubungan sangat signifikan antara kontrol diri dengan kecenderungan perilaku agresif remaja. Hasil perhitungan analisis regresi ganda dengan program SPSS dapat dilihat pada tabel 1 di bawah ini. 


\section{HASIL DAN PEMBAHASAN}

Hasil perhitungan analisis regresi ganda dengan program SPSS dapat terlihat pada tabel 1 Nilai Analisis Regresi .

Tabel 1

Nilai Analisis Regresi

\begin{tabular}{cccc}
\hline \multicolumn{1}{c}{ Variabel } & Koefisien & T hitung & Sig \\
\hline Konstanta & 56,131 & 4,219 &, 000 \\
Peran Ayah & $-0,205$ & $-2,210$ &, 029 \\
Kontrol Diri & 0,333 & 3,556 &, 001 \\
\hline R & 0,356 & & \\
$\mathrm{R}^{2}$ & $0,127(12,7 \%)$ & & \\
$\mathrm{F}$ & $9,054(0,000)$ & & \\
\hline
\end{tabular}

Hasil analisis data menunjukkan:

1. Ada hubungan sangat signifikan peran ayah $\mathrm{dan}$ kontrol diri terhadap kecendrungan perilaku agresif pada remaja dengan $r=0.127 ; p<0.01$.

2. Ada hubungan signifikan signifikan peran ayah terhadap kecendrungan perilaku agresif pada remaja dengan $t=-2.210 ; p<0.05$.

3. Ada hubungan sangat signifikan antara kontrol diri dengan kecenderungan perilaku agresif remaja $\mathrm{t}=3.556 ; \mathrm{p}<0.0$.

Nilai korelasi ganda menunjukkan angka sebesar 0,356. Hal ini menunjukkan bahwa korelasi berganda antara peran ayah dan kontrol diri secara bersama-sama berada di antara $0,00<0,356<1$. Nilai korelasi berada dalam rentang $0<\mathrm{R}<1$ karena ketetapan nilai korelasi tidak melebihi angka 1 untuk memudahkan pemahaman nilai korelasi. Berdasarkan nilai korelasi tersebut dapat diartikan bahwa semakin rendah peran ayah maka diikuti dengan semakin tinggi pula kontrol diri siswa.

Koefisien determinasi ( $R$-square) digunakan untuk mengetahui besarnya hubungan variabel independen yakni peran ayah dan kontrol diri dengan variabel dependen yakni kecendrungan perilaku agresif. Berdasarkan hasil analisis diketahui bahwa nilai $R$ square sebesar 0,127 atau $12,7 \%$ yang berarti bahwa hubungan variabel peran ayah dan kontrol diri siswa sebesar $12,7 \%$, sedangkan sisanya $87,3 \%$ disebabkan oleh variabel lain.

Besarnya sumbangan efektif (SE) dalam bentuk persentase dapat diketahui dari tabel 2 Perhitungan sumbangan efektif dengan hasil perhitungan. Besarnya sumbangan efektif dapat dihitung dari mengalikan korelasi zero order dengan standardized beta. Koefisien korelasi zero order dan standardized coefficient beta dapat diketahui dari hasil perhitungan SPSS. 
Tabel 2.

Perhitungan sumbangan efektif

\begin{tabular}{|c|c|c|c|c|c|c|}
\hline Variabel & $\begin{array}{c}\text { Korelasi } \\
\text { Pearson } \\
(\text { rxy })\end{array}$ & $\begin{array}{l}\mathbf{r x y}^{2} \\
\\
\text { sq }\end{array}$ & $\begin{array}{l}\mathbf{R} \\
\text { uare }\end{array}$ & $\begin{array}{c}\text { Cor.zero } \\
\text { order } \\
\text { (a) }\end{array}$ & $\begin{array}{c}\text { Standardized beta } \\
\text { (b) }\end{array}$ & $\begin{array}{l}\text { SE \% } \\
(\mathbf{a x b})\end{array}$ \\
\hline Peran ayah & $-0,195$ & 0,038 & 0,127 & $-0,195$ & $-0,185$ & 0,036 \\
\hline Kontrol diri & 0,304 & 0,092 & & 0,304 & 0,297 & 0,090 \\
\hline
\end{tabular}

Berdasarkan tabel 2 di atas, diketahui bahwa sumbangan hubungan secara bersama-sama ( $R$ square) peran ayah dan kontrol diri sebesar $12,7 \%$. Besarnya sumbangan efektif masing-masing variabel berdasarkan hasil perhitungan untuk variabel peran ayah dan kontrol diri masingmasing adalah $3,6 \%$ dan $9 \%$, sehingga total $12,6 \%$ mendekati $12,7 \%$.

Uji hipotesis menunjukkan secara bersama-sama ataupun partial menunjukkan ada hubungan peran ayah dan kontrol diri terhadap kecenderungan perilaku agresif pada remaja yakni siswa SMU di Yogyakarta .Hasil penelitian menunjukkan kecenderunagn perilaku agresif remaja disebabkan antara lain faktor peran ayah dan kontrol diri remaja itu sendiri.

Hal ini mengindikasikan pentingnya peran ayah dalam membentuk pribadi anaknya dimulai dari rumah dengan mengutamakan tiga dimensi peran ayah yaitu ketersediaan waktu, kehadiran ayah dan juga kemampuan ayah untuk memenuhi kebutuhan anak, didalam lingkungan pergaulannya ayah tidak dapat langsung menyetop anaknya untuk tidak agresif, karena ayah tidak selalu bersama dengan anaknya. 
Remaja yang mendapatkan dukungan dan adanya komunikasi yang intensif dengan ayahnya memiliki kebebasan yang lebih besar untuk berusaha bereksplorasi untuk menjadi dirinya sendiri, menemukan jati dirinya, mencoba kemampuan dirinya, memperkuat penilaiannya sendiri terhadap pilihan-pilihan yang dibuat dan mempertimbangkan kemungkinannya menghadapi orang lain dalam merencanakan masa depannya yang pada akhirnya mengurangi tingkat kecendrungan melakukan perilaku agresif. Susanto (2013) juga mengatakan bahwa keterlibatan ayah dalam kehidupan remaja akan berhubungan mereka dalam hubungannya dengan teman sebaya dan prestasi di sekolah, serta membantu remaja dalam mengembangkan pengendalian dan penyesuaian diri dalam lingkungannya.

Peran ayah sebagai peran yang dijalankan dalam kaitannya dalam tugas untuk mengarahkan anak menjadi mandiri di masa dewasanya, baik secara fisik maupun psikis. Lingkungan keluarga, khususnya peran ayah dalam memberikan kasih sayang atau pendidikan sosialemosional akhir-akhir ini dirasa kurang menyentuh siswa. Hal ini membuktikan orang tua (ayah), guru dan masyarakat perlu ikut bertanggung jawab dalam proses pendidikan yang telah berjalan (Sugiyono, 2012).

Selain dukungan peran ayah adalah faktor kontrol diri pada remaja menunjukkan hubungan yang kuat terhadap kecendrungan perilaku agresif. Hasil penelitian yang dilakukan oleh Ananta (2013) membuktikan bahwa terdapat korelasi yang negatif signifikan antara kontrol diri dengan tingkat agresif pada remaja. Semakin tinggi kontrol diri seseorang, maka akan semakin rendah tingkat agresif yang dimilikinya.

Penelitian juga sesuai dengan hasil penelitian DeWall, Finkel, dan Denson (2011) yang menyatakan bahwa kegagalan kontrol diri dapat memberikan kontribusi untuk tindakan yang paling agresif yang menyertakan kekerasan. Ketika munculnya perilaku agresif, kontrol diri dapat membantu seseorang merespon sesuai dengan standar pribadi atau sosial yang dapat menahan munculnya perilaku agresi. Kemampuan kontrol diri pada remaja berkaitan dengan bagaimana individu mengendalikan emosi serta dorongan dari dalam dirinya sehingga mampu membuat keputusan dan mengambil tindakan yang efektif terutama untuk membawa mereka sesuai dengan standar ideal, nilai-nilai moral dan harapan sosial.

Dukungan peran ayah turut memberikan kontribusi penting bagi perkembangan anak, dimana pengalaman yang dialami bersama dengan ayah dapat mempengaruhi perkembangan seorang anak hingga dewasa nantinya. Selain itu kemampuan kontrol diri sangat erat kaitannya dengan pengendalian emosi karena pada hakikatnya emosi itu bersifat feedback atau timbal balik. Emosi merupakan bagian dari aspek afektif yang memiliki pengaruh besar terhadap kepribadian dan perilaku seseorang emosi yang bersifat fluktuatif dan dinamis, yang secara normatif menjadi ciri perkembangan remaja. Perubahan emosi sangat tergantung pada kemampuan seseorang dalam mengendalikan diri sehingga saling terkait satu sama lain. 


\section{KESIMPULAN DAN SARAN}

Kesimpulan penelitian ini menunjukkan bahwa peran ayah dan kontrol diri secara bersama-sama memiliki kontribusi atau berperan terhadap kecenderungan perilaku agresif pada remaja siswa SMU di Yogyakarta. Sementara itu secara parsial, peran ayah memiliki hubungan yang kuat terhadap kecenderungan perilaku agresif pada remaja siswa SMU di Yogyakarta. Faktor kontrol diri secara langsung juga berhubungan dengan kecenderungan perilaku agresif remaja siswa SMU di Yogyakarta.

Dalam penelitian ini, beberapa saran diberikan. Saran yang terkait dengan penelitian bagi orangtua khususnya ayah yang berperan dengan perilaku agresif sebagai orangtua untuk mereduksi perilaku agresif siswa. Ayah diharapkan dapat mendidik anaknya melalui dialog dan monitoring dengan anaknya dan terlibat dalam pengasuhan anak. Keluarga juga dapat memperkuat peran ayah atau ibu untuk menanamkan nilai-nilai positif yang dapat meningkatkan kontrol diri. Keluarga dapat memberikan pemahaman akan toleransi, kompromi, saling menghargai, saling asih pada sesama manusia.

Bagi guru kelas dan guru bimbingan konseling perlu mengenal lebih dekat siswa yang memiliki kecenderungan perilaku agresif atau pun yang berperilaku agresif sehingga dapat melakukan intervensi guna menurunkan tingkat perilaku agresif. Bagi kepala sekolah bersama guru bimbingan konseling perlu mendesain hidden curriculum atau menyelipkan kurikulum yang dapat meningkatkan kontrol diri siswa.

\section{Ucapan Terima Kasih}

Peneliti mengucapkan terima kasih kepada beberapa pihak. Yang pertama diucapkan kepada Pimpinan dan guru SMKN ' $X$ ' yang telah mengijinkan kami sebagai peneliti untuk mengambil data. Terima kasih juga disampaikan pada siswa-siswa SMKN ' $X$ ' di Yogyakarta sebagai responden kami.

\section{REFERENSI}

Ananta, M.D. (2013). Hubungan antara self control dengan tingkat agresivitas pada remaja. Universitas Bina Nusantara Jakarta Barat.

Andayani, B \& Koentjoro. (2007). Psikologi keluarga: Peran Ayah MenujuParenting. Sidoarjo: Laros.

Averill, J.R.(1983).Studies on Anger and Aggression, Implication for theories of emotion. American psychologist,38(11),1145-1160.

Badan Pusat Statistik (2010). Profil kriminalitas remaja. Diunduh tanggal 30 Juli 2017 dari http://www.bps.go.id.

Baron, R. A. (2005). Psikologi Sosial. Jakarta : Erlangga. 
Baidi B, (2008). Zikir Al-Asma' Al-Husna. Solusi atas Problem Agresivitas Remaja. Semarang: Syiar Media.

Block, J. Et al. (1988). Parental functioning and the home environment in families of divorce. Journal of the American Academy of Child and Adolescent Psychiatry, 27. Diunduh tanggal 25 Juli 2017 dari http://www.photius.com/.

Buss, A. H., \& Perry, M. (1992). The Aggression Questionnaire. Journal of Personality and Social Psychology, 63(3), 452-459. http://dx.doi.org/10.1037/0022-3514.63.3.452.

Chen, Y.Y. (2017). Determinants of aggressive behavior: Interactive effects of emotional regulation and inhibitory control. Journal University of Granada, SPAIN. 10(15).1-9

Currie, M. (2004). Doing anger differently; A group percussion therapy for angry adolescent boys. International Journal of Group Psychotherapy, 54 (3). 275-294.

DeWall, C.N., Baumeister, R.F., Stillman, T.F. \& Gailliot, M.T. (2007). Violence restrained: Effects of self-regulation and its depletion on aggression. Journal Of Experimental Social Psychology ( IESP ). 43(62). 62-76.

DeWall, C. N., Finkel, E.J. \& Denson, T. F.(2011). Self-control inhibits aggression. Social and Personality Psychology Compass. 5(7). 458-472.

DeWall, C.N., Baumeister, R.F., Stillman,T.F., \& Galliot, M.T. (2013). Violence restrained: Effects of self-regulation and its depletion on aggression. Journal of Experimental Social Psychology. 5(3). 102-120.

Fergusson, D. M., Horwood, L. J., \& Lynskey, M. T. (1994). Parental separation, adolescent psychopathology, and problem behaviors. Journal of the American Academy of Child \& Adolescent Psychiatry, 33(8), 1122- 1131.

Gottfredson, M. R., \& Hirschi, T. (1990). A general theory of crime. Stanford: Stanford University Press.

Gunarsa, S. D. (2007) . Psikologi remaja. Jakarta : Gunung Mulia.

Hoffmann, J. P. (2002). The Community Context of Family Structure and Adolescent Drug Use. Journal of Marriage and Family. 64. 314-330.

Hurlock, E. (2004). Psikologi Perkembangan, Suatu Pendekatan Sepanjang Rentang Kehidupan edisi Kelima. Jakarta: Penerbit Erlangga.

Kandel, D. B; Rosenbaum, E. \& Chen, K. (1994). Impact of Maternal Drug Use and Life Experiences on Preadolescent Children Born to Teenage Mothers. Journal of Marriage and the Family. 56. 325-340.

Kementerian Kesehatan RI. (2014) Pusat data dan informasi. www.depkes.go.id/download.php?file=download. Diunduh tanggal 1 Juni 2017 
Knorth, E.J., Klomp, M., Van der Bergh, P. M., \& Noom, M. J. (2007). Aggresive adolescents in residential care: A selective review of treatment requirements and models. Adolescence, 42 (167), 461-485.

Komisi Nasional Perlindungan Anak (Komnas PA).(2013). Data Tawuran Pelajar tahun 2013. Tersedia di : www.komnaspa.or.id. Diunduh 03 Mei 2017.

Larson, J. (2008). Angry and Aggresive Student, Principal Leadership., 12 - 15 .

Lamb, M. E. (2010). The Role of the Father in Child Development (5th ed). University of Cambridge. United States of America: John Wiley \& Sons, Inc.

Lerner, H. (2011). Losing a Father Too Early. Dipublikasikan pada 27 November 2011 oleh Harriet Lerner dalam The Dance of Connection. [online] http://www.psychologytoday.com/. Diunduh 12 April 2017.

Mahmudah, S. (2010). Psikologi sosial. Malang: UIN Maliki Press.

McMullen, J. C. (1999). A test of self-control theory using general patterns of deviance. (Dissertation). Doctor of Philosophy, Virginia Polytechnic Institute University.

Monks F.J, Knoers, \& Hardianto, S.R. (2001). Psikologi perkembangan (pengantar dalam berbagai bagiannya). Yogyakarta : Universitas Gadjah Mada.

Myers, D.G. (2002). Social psychology. 7th edition. North America : Mc Graw Hill. Inc.

Nisfiannoor, M. \& Yulianti, E. (2005) Perbandingan perilaku agresif antara remaja yang berasal dari keluarga bercerai dengan keluarga utuh. Jurnal Psikologi. 3(1).1-18.

Say. (2016). Berikut Ini Sederet Aksi Klitih Sadis dan Brutal yang Terjadi di Yogyakarta Sepanjang 2016. Diunduh tanggal 31 Maret 2017

di :http://jogja.tribunnews.com/2016/12/14/.

Sarwono, S. W \& Eko A, M. (2009). Psikologi sosial. Jakarta: Penerbit Salemba Humanika.

Sears, D.O, Freedman, J.L \& Peplau, L.A. (1991). Psikologi Sosial. Jakarta: Erlangga.

Susanto, D. (2013). Keterlibatan ayah dalam pengasuhan, kemampuan coping dan resiliensi remaja. Jurnal Sains Dan Praktik Psikologi Magister Psikologi UMM, 1 (2), $101-113$.

Subiyanto, P. (2004). Pentingnya peran ayah dalam keluarga. Diunduh pada 22 April 2017, dari http://www.balipost.co.id/BALIPOSTCETAK/2017/8/1/kell.html.

Sugiyono. (2012). Metode penelitian pendidikan pendekatan kuatitatif dan kualitatif. Bandung: Alfabeta. 
Tremblay \& Cairns. (2000). The development of aggressive behavior during childhood: What have we learned in the past century? International Journal of Behavior Development, 24 (2): $129-141$. 